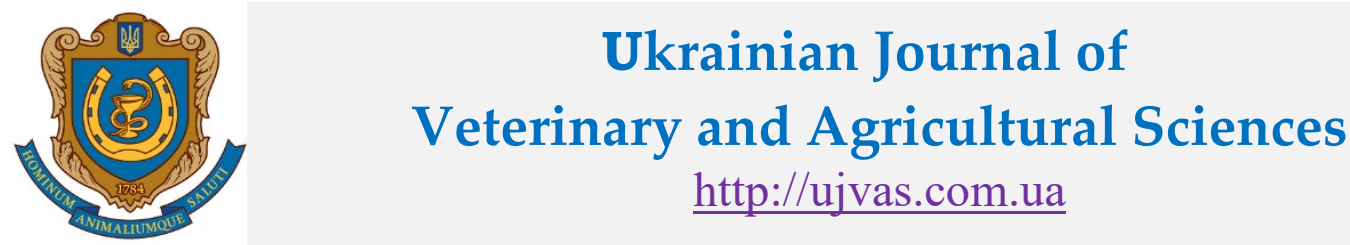

Stepan Gzhytskyi National University of Veterinary Medicine and Biotechnologies Lviv

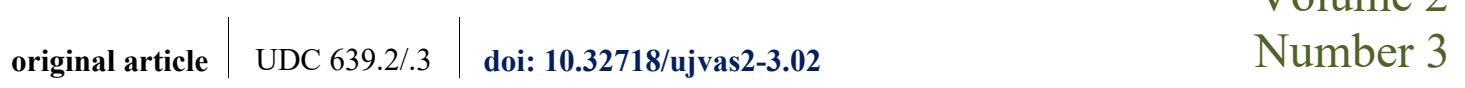

\title{
The current state of fish market in Ukraine
}

\author{
M. I. Burgaz, T. I. Matvienko, K. I. Bezik, O. M. Soborova \\ Odessa State Environmental University, Lvivska Str., 15, Odessa, 65016, Ukraine
}

\begin{tabular}{l} 
Article info \\
Received 24.10.2019 \\
Received in revised form \\
02.12 .2019 \\
Accepted 03.12.2019 \\
\hline Correspondence author \\
Maryna Burhaz \\
Phone: +38-067-990-49-26 \\
E-mail: marinaburgaz14@gmail.com \\
\hline
\end{tabular}

2019 Burgaz M. I. et al. This is an open-access article distributed under the terms of the Creative Commons Attribution License, which permits unrestricted use, distribution, and reproduction in any medium, provided the original author and source are credited.

\section{(cc) $\mathrm{BY}$}

Contents

1. Introduction

3. Results and discussion ...... 7

4. Conclusions

References ................... 9

\begin{abstract}
The fishing industry is an important component of the economy of Ukraine at the present stage of development. The development and implementation of the innovative technologies in fish farming and fish processing require mandatory and ongoing analysis of a fish market infrastructure. The demand for food protein, which is characterized by a balanced amino acid content is provided by fish and seafood at $20-30 \%$. The aim of this work was to understand a current state of a fish products market in Ukraine, its pricing and consumption. Based on the specialized literature the evaluation of a current state of fish and fish products consumption in Ukraine and own studies of the price category of fish products in Ukraine in recent years were conducted. We studied fish and fish products consumption per year per capita in Ukraine over the last 20 years, assortment of fish in Ukraine, the import of fish and fishery products by species, the product prices in UAH per kg both in previous years and today. According to international medical standards the annual consumption of fish and seafood should be $20 \mathrm{~kg}$ per person. At the same time in Ukraine according to the State Statistics Committee on the $01.01 .201914 .5 \mathrm{~kg}$ of fish and seafood came out per capita. In 2018-2019 herring traditionally remained a leader of consumption in Ukraine. Ukraine also imported such species of fish: mackerel, hake, herring, salmon, pilchards, pollack, capelin, sardines, notating. In addition pangasius, shrimp, blue whiting, mussels, squid, saury, Jack mackerel, sea bass, tuna, flounder, anchovies, smelt, cod, salmon and other species of fish, caviar and seafood are imported in Ukraine. The investigated assortment of fish in Ukraine is represented both domestic and imported products. The domestic production are: carp, pike, capelin, herring, mackerel, sprat, the imported products are: flounder, perch, pangasius, salmon, butter, hake, Pollock, capelin, nototenia, herring, mackerel, cod, tuna, tilapia (sole), sea trout, whiting and so forth. It is established that the condition of a fish market in Ukraine is affected by an unstable economic and political situation in the country, low solvency of the population, corruption and the high payables of the enterprises. In Ukraine a tendency towards a decrease in the volume of fish and fish products consumption by the population of Ukraine is observed annually, which is a consequence of the decline in fish catch and fish production, depreciation of fixed assets and a lack of financial support to the fishing industry.
\end{abstract}

Key words: fish market, fishing industry, fish, seafood, consumption volumes, imports, consumption, price policy, production, fish farming.

\section{Citation:}

Burgaz, M. I., Matvienko, T. I., Bezik, K. I., \& Soborova, O. M. (2019). The current state of fish market in Ukraine. Ukrainian Journal of Veterinary and Agricultural Sciences, 2(3), 6-10.

\section{Introduction}

Fish, seafood and other live aquatic organisms is not only a valuable source of protein and essential microelements for balanced nutrition and good health, but also a source of raw material for agriculture, pharmaceutical, cosmetic and other industries. A unique feature of aquatic bioresources is their ability to reproduce, and the technologies of artificial fish breading is based on the natural process of fish and other aquatic organisms reproduction (Demchuk \& Dracheva, 2013; Shevchenko, 2014; Kleshhsvsknj et al., 2017).

The fishing industry is an important component of the economy of Ukraine at the present stage of development. The development and implementation of the innovative technologies in fish farming and fish processing require mandatory and ongoing analysis of the infrastructure of a fish market. The demand for food protein, which is charac- terized by a balanced amino acid content is provided by fish and seafood at 20-30\%.

The aim of this work was to establish a current state of a fish products market in Ukraine, a price policy and consumption.

To achieve the goal the next tasks were set:

1. To perform a condition of a fish products market in Ukraine;

2. To determine a share of imported products and to identify the branches for increasing a share of a domestic products market in Ukraine;

3. To perform a modern price category of fish and fish products in Ukraine

\section{Materials and methods}

Based on the specialized literature the evaluation of a current state of fish and fish products consumption in Agricultural Sciences, 2019, Vol. 2, N 3 
Ukraine and own studies of a price category of fish products in Ukraine in recent years were conducted.

\section{Results and discussion}

The world fisheries are steadily increasing the production (catch) of fish, seafood and aquaculture products. The growth rate of world fish catch is ahead of the growth rate of the Earth's population, which characterizes the world fisheries as dynamically developing with inexhaustible growth potential.

The fisheries sector includes ocean and marine fisheries, inland water bodies, fisheries (aquaculture), fish processing agricultural enterprises, fish stocks reproduction and conservation organizations, marine fishing ports, scientific and educational institutions. Fish and fish products, valuable and often indispensable food, provides a human need primarily in proteins of animal origin, a wide range of vitamins, a variety of microelements and biologically active substances.

According to the international medical standards annual consumption of fish and seafood should be $20 \mathrm{~kg}$ per person. At the same time in Ukraine according to the State Statistics Committee there are only $14.5 \mathrm{~kg}$ of fish and seafood per person on the 01.01.2019 (Derzhavna sluzhba statystyky Ukrainy). In turn in recent years there has been an increase in a level of the hydrobionts consumption (Fig. 1) (Derzhavna sluzhba statystyky Ukrainy).

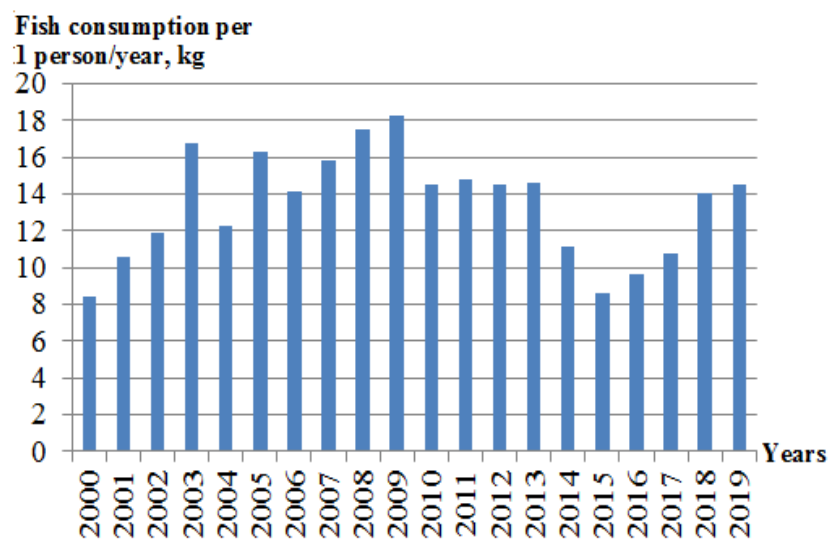

Fig. 1. Consumption of fish and fishery products per year per capita, kg (according to the State Statistics Committee of Ukraine)
According to the State Statistics Committee of Ukraine in 2019, in Ukraine consumption of fish and fishery products per capita increased to 14.5 kilograms, which can be attributed to the increase in imports and a slight increase in the volume of own production in the certain branches of fisheries.

Between 2000 and 2019 consumption of fish and fishery products (per year per capita) varied from 8.4 in 2000 to 18.3 in 2009. Today consumption of fish and fishery products by the Ukrainians is $14.5 \mathrm{~kg}$ per year per capita. From 2001 to 2014 this figure was increasing, and in 2015 it dropped to 8.6 kilograms, which can be largely attributed to the decrease in imports of fish and fishery products to Ukraine. Since 2016 consumption of fish and fishery products by the Ukrainians has begun to increase. However the FAO recommended rate of fish consumption is $20 \mathrm{~kg}$ per capita per year. At the same time marine fish should be $75 \%$ of a stated norm.

In almost all countries of the world consumption of fish and seafood is higher than in Ukraine (Table 1) (COFI: FT/XVI/2017/2, 2017).

Table 1 shows consumption of fish per capita in the World with the exception of whales, seals and other marine mammals, and marine plants. The total values may differ from the sums of additions through rounding.

In the late nineteenth century 47 percent of global fish consumption was in Europe, the United States of America and Japan, but today a share of these countries decreased by about 20 percent.

In 2018-2019 herring traditionally remained the leader of consumption in Ukraine. Ukraine also imported such species of fish: mackerel, hake, herring, salmon, pilchards, pollack, capelin, sardines, notating (Shevchenko, 2014).

In addition pangasius, shrimp, blue whiting, mussels, squid, saury, Jack mackerel, sea bass, tuna, flounder, anchovies, smelt, cod, salmon and other species of fish, caviar and seafood are imported in Ukraine (Ahrarni novyny ta operatyvna statystyka).

Today Ukraine imports about $90 \%$ of the fish. This situation is due to a lack of a profile fleet, the processing industry, the quotas in international waters and poaching. In addition the cost of Ukrainian fish is higher than imported one. Therefore the products lose their competitiveness (Shevchenko, 2014).

Table 1

Fish consumption per capita in the world, (kg per year) *

\begin{tabular}{|c|c|c|c|c|c|c|c|}
\hline & 2014 & 2015 & 2016 & 2017 & $2026 *$ & $\begin{array}{c}\text { Changes to } \\
2017 \text { compared } \\
\text { to } 2016 \\
\end{array}$ & $\begin{array}{c}\text { Changes by } \\
2026 \text { compared } \\
\text { to } 2016\end{array}$ \\
\hline $\begin{array}{l}\text { Total fish } \\
\text { consumption }\end{array}$ & 20.1 & 20.3 & 20.4 & 20.4 & 21.6 & 0.1 & 5.8 \\
\hline $\begin{array}{l}\text { From industrial } \\
\text { fisheries }\end{array}$ & 10.0 & 9.9 & 9.6 & 9.6 & 9.1 & -0.8 & -4.9 \\
\hline Aquaculture & 10.1 & 10.5 & 10.7 & 11.0 & 12.5 & 2.6 & 13.3 \\
\hline
\end{tabular}

* According to: COFI: FT / XVI / 2017/2 3

* Source for 2026: FAO Fisheries Modeling in the OECD-FAO Agricultural Forecast for 2017-2026.

In General Ukraine imports fish and seafood from 60 countries.

Norway is a traditional leader in imports of fish in Ukraine. The USA is in the second place. Estonia, Latvia,
Spain, Canada, UK, China, Vietnam and Argentina are the next.

An assortment of fish in Ukraine is represented by both domestic and imported products: 
- Domestic products: carp, pike, capelin, herring, mackerel, few.

- Imported products: flounder, perch, pangasius, salmon, butter, hake, Pollock, capelin, nototenia, herring, mackerel, cod, tuna, tilapia (sole), sea trout, hake, etc (Fig. 2).

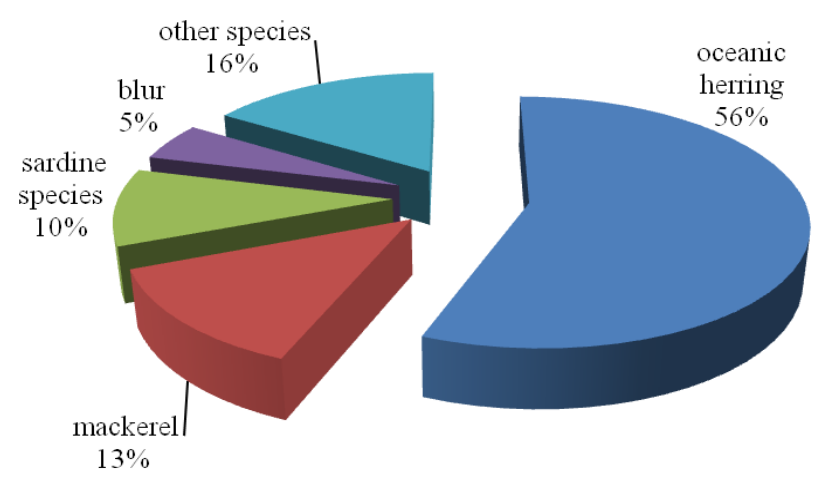

Fig. 2. Imports of fish and fish products by species
Considering the import by fish species it should be noted that the oceanic herring accounts for $56 \%$; mackerel $13 \%$; sardine species $-10 \%$; pollock $-5 \%$. The other $16 \%$ of the import are from such fish as salmon, several, capelin, whiting, hake and others. Atlantic herring and mackerel are imported to Ukraine from Norway. Sardines are also imported from Norway, the USA, Canada, Spain and Argentina. Sprat is mostly Baltic. Pollock and salmon are imported from Russia and Norway. France, Italy and China are the main importers of delicate fish species (Stets, 2017).

Now the most popular types of domestic products include carp, pike, several, pelengas. Mackerel $(15.5 \%$ of the total number of fish) has become the most popular marine fish caught in Ukraine, $13.3 \%$ is scallop, $8.4 \%$ is tusk, $10.1 \%$ is krill. Carp (10.6\%), silver carp (13.6\%) and crucian $(5.1 \%)$ are the leaders among river fish (But, 2017).

The cost of fishery products and seafood imported into Ukraine in 2014 (Novyny Ukrainy) averaged 61.80 UAH per $\mathrm{kg}$ and in 2019 it was 121,12 UAH per kg (Table 2).

Table 2

Products prices in UAH per kg (2014 and 2019)

\begin{tabular}{|c|c|c|c|c|}
\hline \multirow[b]{2}{*}{ Types of fishes } & \multicolumn{2}{|c|}{2014} & \multicolumn{2}{|c|}{2019} \\
\hline & $\begin{array}{l}\text { The average } \\
\text { price, UAH. }\end{array}$ & $\begin{array}{l}\text { The max. price, } \\
\text { UAH. }\end{array}$ & $\begin{array}{l}\text { The average } \\
\text { price, UAH. }\end{array}$ & $\begin{array}{c}\text { The max. price, } \\
\text { UAH. }\end{array}$ \\
\hline Carp is alive. open. & 40 & 45 & 79,46 & 208,16 \\
\hline The flounder cools. imports & 52 & 56 & 63,87 & 120 \\
\hline Sea bass cooled. imports & 30 & 32 & 119,9 & 145 \\
\hline Pangasius fillet $\mathrm{s} / \mathrm{m}$ import & 42 & 44 & 130 & 150 \\
\hline Salmon cool. imports & 122 & 126 & 400 & 520 \\
\hline Salmon steak cooled. imports & 143 & 146 & 339,9 & 419,9 \\
\hline Pike cooled. is open. & 52 & 55 & 119,9 & 150 \\
\hline Merlush c / m imports & 55 & 57 & 68,5 & 100 \\
\hline Mintai agricultural imports & 38 & 39,9 & 62 & 80 \\
\hline Pollock fillet c / m import & 40 & 42 & 77 & 95 \\
\hline Capel c / m imports & 23 & 23 & 32,9 & 50 \\
\hline Nototeniya agricultural imports & 38 & 39 & 96,1 & 123,4 \\
\hline Sea bass fillet c / $\mathrm{m}$ import & 72 & 75 & 160 & 325 \\
\hline Herring $(350+) \mathrm{c} / \mathrm{m}$ imports & 26 & 28 & 49,99 & 76,3 \\
\hline $\begin{array}{l}\text { Mackerel }(400+) \text { agricultural } \\
\text { imports }\end{array}$ & 57 & 59 & 69,1 & 98,1 \\
\hline Tilapia (sea tongue) $\mathrm{s} / \mathrm{m}$ import & 75 & 75 & 120 & 150,4 \\
\hline Trout sea b / w with / m import & 72 & 74 & 159,9 & 249,9 \\
\hline Hake s / m imports & 54 & 60 & 69,9 & 180 \\
\hline Capelin x / p. & 32 & 35 & 123 & 145 \\
\hline Salaka x / p. & 40 & 46 & 62 & 65 \\
\hline Mackerel $\mathrm{x}$ / a native & 44 & 48 & 140 & 175 \\
\hline
\end{tabular}

(2014 according to the State Statistics Committee of Ukraine, 2019 own data)

The average cost of fish and fishery products of the lower price segment on the Ukrainian stalls is $50-80 \mathrm{UAH} / \mathrm{kg}$, while the fish and marine products of the higher price segment cost about $150-350 \mathrm{UAH} / \mathrm{kg}$. Thus from the moment of fish and seafood delivery to the border of Ukraine till their appearance in the retail trade, the cost of these products increases on average by $8-10$ times. 


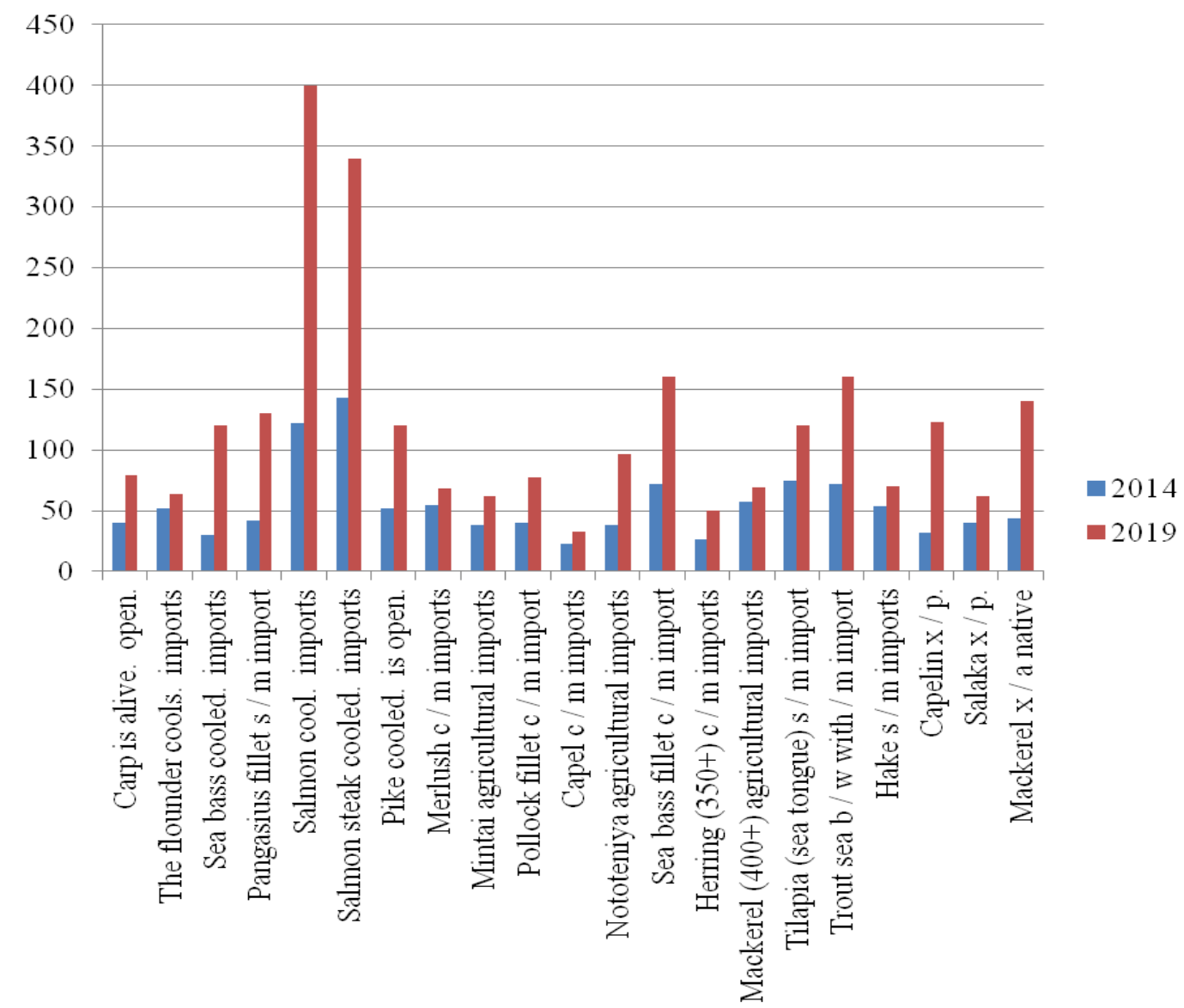

Fig. 3. Comparison of average prices for fish products in UAH per kg in 2014 and 2019 (2014 according to the State Statistics Committee of Ukraine, 2019 own data)

As can be seen from Fig. 3 the average prices for all fishery products in Ukraine have increased significantly. Comparing the average prices in 2014 and 2019 it can be noted that salmon chilled (328\%), salmon steak (238\%), pike chilled $(231 \%)$, sea bass $(222 \%)$, trout $(221 \%)$ and mackerel $(318 \%)$ have risen most in price.

Fish prices in 2014 compared to 2019 increased 3-4 times and now continue to grow rapidly. Such a rapid growth is explained by an unstable economic and political situation in the country as well as by inflation, which amounted to $12-14 \%$ during this period.

Consequently consumption of fish in Ukraine remains a problem. The residents of the country eat half as much fish as the European average, and fish and fishery products are generally inaccessible to the most segments of the population.

\section{Conclusions}

The state of a fish market in Ukraine is affected by an unstable economic and political situation in the country, low solvency of the population, corruption and high debt of the enterprises.

In Ukraine the tendency to decrease the volume of fish products consumption by the population of Ukraine is observed annually (the Ukrainian eats only 14 kilograms of fish per year on average, but he must eat 20 or more $\mathrm{kg}$ ), which is a consequence of the decline in fish catches and fishery production, deterioration of the main funds and insufficient financial support for the fishing industry.
Ukraine currently imports about $90 \%$ of fish. This situation is due to a lack of a specialized fleet, the processing industry, the quotas in neutral waters and poaching.

The cost of Ukrainian fish is higher than the import price, so the products lose their competitiveness.

A pricing strategy is mainly related to a price reduction. Realization of this direction can be fully achieved only with the active participation of the state and through financing the various spheres of fishery enterprises activity.

Considerable investments and time are required to solve all the problems, but today there are shifts for the better in the development of the fishing industry of Ukraine and with the support of the state the fishing industry will become one of the most powerful industries in the agrarian complex of Ukraine.

\section{References}

Ahrarni novyny ta operatyvna statystyka [Elektronnyi resurs] Rezhym dostupu: http://agroua.net (in Ukrainian).

But, O. (2017). Svit produktiv [Elektronnyi resurs] Rezhym dostupu: http://uifsa.ua/uk/news/news-of-ukraine/fish-marketsurvey-for-magazine-world-of-products (in Ukrainian).

COFI: FT/XVI/2017/2 (2017). [Jelektronnyj resurs] Rezhym dostupu: http://docplayer.ru/77598012-Komitet-po-rybnomuhozyaystvu.html (in Russian).

Demchuk, O. V., \& Dracheva, M. V. (2013). Sovremennoe sostojanie rybnoj otrjasli i perspektivy razvitija rynka rybnoj produkcii v Ukraine. Rybne hospodarstvo Ukrainy, 5, 47-51. Rezhym dostupu: http://nbuv.gov.ua/UJRN/rgu_2013_5_10 (in Russian). 
Derzhavna sluzhba statystyky Ukrainy [Elektronnyi resurs] Rezhym dostupu: http://www.ukrstat.gov.ua (in Ukrainian).

Kleshhsvsknj, O. N., Nikolaeva, M A., \& Rjashioii, O. A. (2017). Sovremennoe sostojanie i perspektivy razvitija rynka ryby $\mathrm{i}$ rybnyh tovarov $\mathrm{v}$ Rossii I Vestnik Kemerovskogo gosudarstvennoju universnisia. Serija: Politicheskie, sociologicheskie i zhonomichsskie nauki, 3, 34-42. https://cyberleninka.ru/article/n/sovremennoe-sostoyanie-iperspektivy-razvitiya-rynka-ryby-i-rybnyh-tovarov-vrossii/viewer (in Russian).
Novyny Ukrainy [Elektronnyi resurs] Rezhym dostupu: http://uifsa.ua/uk/news/news-of-ukraine (in Ukrainian).

Shevchenko, D. (2014). Rynok rybnogo hozyajstva Ukrainy [Elektronnij resurs]. Rezhym dostupa: https://inventure.com.ua/analytics/investments/rynok_rybnogo hozyajstva_ukrainy (in Russian).

Stets, T. (2017). 85\% importu i skorochennia spozhyvannia vtrychi. Ukrainska rybna haluz na mezhi znyknennia. [Elektronnyi resurs] Rezhym dostupu: http://asn.in.ua/ua/news/publishing/97553-85-importnojjprodukcii-i-sokrashhenie-potrebleni.html (in Ukrainian). 